\title{
Anti-staphylococcal Effectiveness of Nisaplin in Refrigerated Pizza Doughs
}

\author{
Wilma Carla de Freitas ${ }^{1}$, Evandro Leite de Souza ${ }^{2 *}$, Cristina Paiva de Sousa ${ }^{3}$ and Antônio \\ Eustáquio Resende Travassos ${ }^{1}$ \\ ${ }^{I}$ Departamento de Tecnologia Química e Alimentos; Centro de Tecnologia; Universidade Federal da Paraíba; João \\ Pessoa - PB - Brazil. ${ }^{2}$ Departamento de Nutrição; Centro de Ciências da Saúde; Universidade Federal da Paraíba; \\ evandroleitesouza@bol.com.br; João Pessoa - PB - Brazil. ${ }^{3}$ Departamento de Patologia e Morfologia; Centro de \\ Ciências Biológicas e da Saúde; Universidade Federal de São Carlos; São Carlos - SP - Brazil
}

\begin{abstract}
This study evaluated the effectiveness of nisaplin, commercial product having nisin as active component, in decreasing the staphylococcal population in refrigerated pizza doughs. The refrigerated pizza dough pieces randomly chosen were dipped in the solutions with nisaplin concentrations of $1.0 \times 10^{-3} \mathrm{~g}$ and $1.0 \times 10^{-2} \mathrm{~g}$ nisaplin/mL named for the treatment $A$ and $B$ and kept under refrigeration $\left(7^{\circ} \mathrm{C} \pm 1{ }^{\circ} \mathrm{C}\right)$. On times 0,15 and 30 days post treatment the Staphylococcus spp. count was carried out. The results showed that both nisaplin treatments were able to reduce the Staphylococcus spp. count (CFU/g) in the refrigerated pizza doughs. However, only treatment $B$ showed statistically significant reducer effect $(p<0.05)$ on the count providing a decrease of 1.0 and $0.98 \log$ cycles, respectively, after 15 and 30 days post treatment. These data suggest that nisin could appear as promising alternative to control the survival of the pathogen microorganisms in the foods, particularly, Staphylococcus in the refrigerated pizza doughs.
\end{abstract}

Key words: Nisaplin, nisin, dough, Staphylococcus

\section{INTRODUCTION}

There has been a trend to consume the fresh foods in respect of the frozen foods, hence the consumption of the refrigerated foods has progressively increased. The refrigerated pizza doughs are recognized as excellent substrates for the microbial growth being necessary to apply some procedures in order to control the growth and microbial survival in/on them (Cabo et al., 2001). Several authors have reported high microbial contamination in the food doughs (Stevens et al., 1992; Freitas et al., 2004).

Staphylococcus has been known as pathogen microorganisms able to survive in the refrigerated pizza doughs (Freitas et al., 2004). Capsule, peptideglycan, A protein, adhesins, outcell enzymes, outcell toxins, leukocidins and hemolysins are some virulence attributes found in Staphylococcus (Trabulsi et al., 2002). S. aureus has been most often associated to staphylococcal diseases causing gastroenteritis due its capability to synthesize a thermostable toxin (Brooks et al., 1998).

In recent years, the use of alternative compounds to be applied in food bioconservation systems has been emphasized (Brul and Coote, 1999; Devlieghere and Debevere, 2004). The biopreservation is a widely accepted food conservation system being referred as natural

*Author for correspondence 
procedure able to provide the shelf-life extension and increased microbial food safety (Fiorentini et al., 2001).

Bacteriocins are proteic molecules with wide antimicrobial properties and synthesized when some microbial lineages are exposed to stressful conditions (e.g., nutrients depletion and overpopulation) (Cleveland et al., 2001). The application of nisin (a bacteriocin) in foods has been allowed in various countries to inhibit the survival of foodborne pathogens in the dairy products, canned goods, vacuum-packed meat and cold smoke salmon (Abee et al., 1994; Shefet et al., 1995; Davies, 1999; Nilsson et al., 2000). Some favorable attributes found in nisin are: i) toxicity absence; ii) naturally produced by Lactococcus lactis; iii) heat stability; iv) storage stability; v) degradation by digestive enzymes; vi) not proportionate undesired taste and flavor to foods; and vii) have prominent antimicrobial spectrum against Gram-positive microorganisms (Kominsky, 1999; Fiorentini et al., 2001).

This study aimed to evaluate the effectiveness of nisaplin, commercial product containing nisin as active compound, to reduce the staphylococcal population in the refrigerated pizza doughs.

\section{MATERIAL AND METHODS}

\section{Refrigerated pizza dough samples}

Twelve refrigerated pizza dough samples from two different commercial brands $\left(\mathrm{PD}_{1}\right.$ and $\left.\mathrm{PD}_{2}\right)$ were randomly chosen and collected from the supermarkets of João Pessoa city, Paraíba, Brazil. These samples were cut in pieces of approximately $50 \mathrm{~g}$. Two pieces of each sample were randomly chosen and kept in the plastic commercially sterile recipients under refrigeration $\left(7^{\circ} \mathrm{C} \pm 1{ }^{\circ} \mathrm{C}\right)$ until the experimental assay.

\section{Experimental assay: nisaplin treatment}

Independent variable of this study was the nisaplin content $\left(10^{6} \mathrm{IU} \mathrm{g}^{-1}\right.$ of nisin, Aplin and Barret Ltd. Dorset, UK). The effect of nisaplin at two different concentrations was analyzed: $1 \times 10^{-3} \mathrm{~g}$ nisaplin/mL $\left(10^{3} \mathrm{IU}\right.$ nisin $\left./ \mathrm{mL}\right)$ and $1 \times 10^{-2} \mathrm{~g}$ nisaplin/mL $\left(10^{4} \mathrm{IU}\right.$ nisin/mL) named treatment $\mathrm{A}$ and treatment $B$, respectively. Nisaplin solutions were prepared in the sterile $0.02 \mathrm{~N} \mathrm{HCL}$ prior the experimental assay (Shefet et al., 1995). Nisaplin treatment was carried out by dipping the refrigerated pizza dough pieces for one minute in
$100 \mathrm{~mL}$ of different nisaplin solutions. After draining, each piece was put into a plastic commercially sterile recipient and kept under refrigeration $\left(7^{\circ} \mathrm{C} \pm 1{ }^{\circ} \mathrm{C}\right)$. Control assay was carried out by dipping the pizza dough pieces in $100 \mathrm{~mL}$ of sterile $0.02 \mathrm{~N} \mathrm{HCl}$ and the next steps were the same described for nisaplin treatment.

\section{Microbiological analyses}

On 0,15 and 30 days post nisaplin treatment the Staphylococcus spp. count was carried out (Vanderzant and Splittstoesser, 1992). Initially, each refrigerated pizza dough piece was weighed and prepared serial dilutions $\left(10^{-1}-10^{-4}\right)$ using $0.01 \%(\mathrm{w} / \mathrm{v})$ sterile peptone water. Afterwards, $0.1 \mathrm{~mL}$ of each dilution was inoculated by spread plate procedure into sterile Baird-Parker Petri dishes (added of egg yolk emulsion and potassium telurite to $1 \% \mathrm{v} / \mathrm{v})$. After incubation at $37^{\circ} \mathrm{C}$ for $48 \mathrm{~h}$ the colonies of Staphylococcus ssp. were counted. The colonies which were circular, black, small, even, convex and with perfect borders surrounded by opaque halo were considered Staphylococcus spp. typical colonies. All the assays were performed twice and the results regarding the Staphylococcus spp. count and reduction were expressed in $\log \mathrm{CFU} / \mathrm{g}$ and $\log$ cycles, respectively.

\section{Statistical analysis}

An experimental delineation $2 \times 3 \times 3$ (two pizza dough kinds, two different nisaplin concentrations and control assay, three times post nisaplin treatment) was used. Student t-test was used to verify statistically significant differences ( $p<$ 0.05). For this, the Statistical Analysis System (SAS) Institute was used.

\section{RESULTS AND DISCUSSION}

Nisaplin effect on Staphylococcus spp. count in the refrigerated pizza doughs is shown in Fig. 01. The treatment B $\left(1.0 \times 10^{-2} \mathrm{~g}\right.$ nisaplin $\left./ \mathrm{mL}\right)$ presented statistically significant inhibitory effect ( $p<0.05)$ on the staphylococcal count. It was able to cause a reduction of 1.1 and $0.98 \log$ cycles on the count after times 15 and 30 days posttreatment (PT), respectively, when compared to the control assay. The treatment B showed Staphylococcus spp. count on 0 day PT of $4.91 \mathrm{log}$ $\mathrm{CFU} / \mathrm{g}$, followed for counts of 4.09 and $3.90 \mathrm{log}$ $\mathrm{CFU} / \mathrm{g}$ on 15 and 30 days PT, respectively. 
The treatment B provided a highest reduction in the number of Staphylococcus until the time 15 days PT suggesting the occurrence of a selection of more resistant Staphylococcus strains to the applied treatment. Possibly, from 15 days PT on, the ones could have taken larger relative proportion in the total number of reminiscent Staphylococcus cells and, possibly, provided a smaller reduction in the staphylococcal population as found on 30 day PT. Some food-borne pathogens when exposed to inimical procedures could exhibit an initial exponential kill proceeded by a "tail section" that indicate an apparently increased resistance in the later stages of the exposure. These survivors were likely to be physiologically protected front the stress and were not mutants (Rowan, 1999).

The treatment A $\left(1.0 \times 10^{-3} \mathrm{~g}\right.$ nisaplin $\left./ \mathrm{mL}\right)$ presented decreasing effect on the staphylococcal population in the refrigerated pizza doughs on 0 and 15 days PT; however it was not statistically significant $(\mathrm{p}<0.05)$. The refrigerated pizza doughs exposed to the treatment A showed a Staphylococcus spp. growth curve similar to that found for the control assay along the evaluated times.

Other authors have noted the role of bacteriocins from Lactobacillus plantarum $\mathrm{BN}$ in improving the shelf-life of the refrigerated bovine meat (Fiorentini et al., 2001) and effectiveness of the concomitant application nisin/EDTA in inhibiting the growth of Gram-negative bacteria (Salmonella tiphymurium. S. infantis, $S$. heidelberg, $S$. choleraesuis, E. coli 0157:H7) (Stevens et al., 1992; Cutter and Siragusa, 1995). Shefet et al. (1995) found inhibitory effect of nisin when applied in combination of ETDA and citric acid on $S$. typhimurium in chicken meat.
The Staphylococcus spp. average count found for each brand of refrigerated pizza dough when exposed to treatment $\mathrm{B}$ on 0,15 and 30 days PT are shown in Table 1. It was found that the antistaphylococcal activity of nisaplin was depending on the pizza dough brand and time PT. AntiStaphylococcus spp. activity was noted only after 30 days PT and it was more intense in the assay with $\mathrm{PD}_{2}$ (difference of $1.28 \mathrm{log}$ cycles between the counts in $\mathrm{PD}_{1}$ and $\mathrm{PD}_{2}$ ). On 30 days $\mathrm{PT}$, a statistically significant difference $(\mathrm{p}<0.05)$ between the Staphylococcus spp. counts found in $\mathrm{PD}_{1}$ and $\mathrm{PD}_{2}$ was noted. Larger or smaller nisin antimicrobial effectiveness depends on the bacterial species, bacterial growth phase, substrate composition and environment conditions as $\mathrm{pH}$ and storage temperature (Moreno et al., 2000).

Nisin inhibitory action on Staphylococcus species occurs in two stages. The first stage involves unspecific interaction between the nisin molecule and target bacterial cytoplasmic membrane characterized as reversible and $\mathrm{pH}$-dependent phenomenon. At the second stage, the nisin molecule and target bacterial cytoplasmic membrane present a strong attraction leading to the formation of the channels with $0.1-0.2 \mu \mathrm{m}$ diameter in the bacterial cytoplasmic membrane. The Simultaneous cytoplasmic membrane depolarization provides fast flux of essential molecules $\left(\mathrm{K}^{+}\right.$ions, aminoacids, ATP) resulting in cell lyses (Moreno et al., 2000).

The results obtained in this study indicated potentiality of nisin as alternative antimicrobial compound to use in the food conservation. Nisaplin, commercial product having nisin as active component, was able to provide statistically significant reduction of Staphylococcus spp. in the refrigerated pizza doughs.

Table 01 - Staphylococcus spp. count average $(\log \mathrm{CFU} / \mathrm{g})$ in refrigerated pizza doughs submitted to nisaplin treatment B $(1.0 \mathrm{x}$ $10^{-2} \mathrm{~g}$ nisaplin $/ \mathrm{mL}$ ) and stored at $7{ }^{\circ} \mathrm{C}$.

\begin{tabular}{lccc}
\hline Pizza dough & \multicolumn{3}{c}{ Times post nisaplin treatments (days) } \\
\cline { 2 - 4 } & 0 & 15 & 30 \\
\hline $\mathrm{PD}_{1}{ }^{\mathrm{a}}$ & 4.85 & 5.04 & 4.98 \\
$\mathrm{PD}_{2}{ }^{\mathrm{b}}$ & 4.97 & 5.08 & 3.70 \\
\end{tabular}

a pizza dough brand $1 ;{ }^{\mathrm{b}}$ pizza dough brand 2 


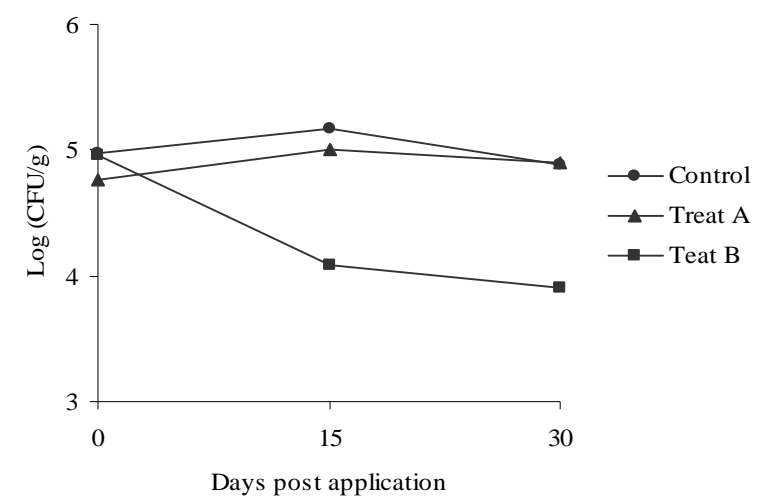

Figure 01 - Staphylococcus spp. count average (log CFU/g) in refrigerated pizza dough submitted to two different treatments using nisaplin as interfering variable and stored at $7{ }^{\circ} \mathrm{C}$

Nisaplin, commercial product having nisin as active component, was able to provide statistically significant reduction of Staphylococcus spp. in the refrigerated pizza doughs. Nisin, and possibly other bacteriocins, could act on/in the microbial cell through the unconventional mechanisms providing inhospitable conditions to the microbial survival. Moreover, some studies could be carried out to evaluate the antimicrobial effectiveness of nisin in pizza doughs when applied jointly with other antimicrobial procedures used in the food conservation.

\section{RESUMO}

Este estudo avaliou a efetividade de nisaplin, produto comercial tendo nisina como componente ativo, em diminuir a população estafilocócica em massas de pizza refrigeradas. Pedaços de massa de pizza refrigerada foram randomicamente escolhidos e mergulhados em soluções de nisaplin com concentração de $1.010^{-3} \mathrm{~g}$ e $1.0 \quad 10^{-2} \mathrm{~g}$ nisaplin $/ \mathrm{mL}$, nomeados, respectivamente, tratamento A e B, e mantidos sob refrigeração (7 ${ }^{\circ} \mathrm{C} \pm 1{ }^{\circ} \mathrm{C}$ ). Nos tempos 0 , 15 e 30 dias póstratamento foram feitas as contagens de Staphylococcus spp. Os resultados mostraram que ambos os tratamentos diminuíram a contagem (UFC/g) de Staphylococcus spp. em massas de pizza refrigeradas. Entretanto, somente o tratamento B mostrou um efeito redutor estatisticamente significante $(\mathrm{p}<0.05)$ sobre a contagem de Staphylococcus spp. causando uma diminuição de 1.0 e 0.98 ciclos logarítmicos, respectivamente, nos tempos 15 e 30 dias pós tratamento. Estes dados sugerem que nisina poderia apresentar-se como uma promissora alternativa para controlar o a sobrevivência de microrganismos patógenos em alimentos, particularmente, espécies de Staphylococcus em massas de pizza refrigerada.

\section{REFERENCES}

Abee, T.; Roumboust, F.M.; Hungenhaltz, J.; Gruhard, G. and Letellier, L. (1994), Mode of action of nisin Z against Listeria monocytogenes scott grawn at high and low temperatures. Appl. Environ. Microbiol., 60, 1962-1968.

Brooks, G.F.; Butel, J.S. and Orsnston, L.N. (1998) Microbiologia médica. Guanabara Koogan, Rio de Janeiro.

Brull, S. and Coote, P. (1999), Preservatives agents in food: mode of action and microbial resistance mechanisms. Int. J. Food Microbiol., 50, 1-17.

Cabo, M. L.; Pastoriza, L.; Bernádez, M.J and Herrera, J.R. (2001), Effectiveness of $\mathrm{CO}_{2}$ and Nisaplin on increasing shelf-life of fresh pizza. Food Microbiol., 18, 489-498.

Cleveland, J.; Mantiville, T.J.; Ness, I.F. and Chiknids, M.L. (2001), Bacteriocins: safe antimicrobials for food preservation. Int. J. Food Microbiol., 71, 1-20.

Cutter, C.N. and Siragusa, G.R. (1995), Treatments with nisin and chelators to reduce Salmonella and Escherichia coli on beef. J. Food Protect., 57, 10281030 . 
Davies, E.A. (1999), Effective use of nisin to control lactic acid bacterial spoilage in vacuum-packed bologna-type sausage. J. Food Protect., 9, 10041010.

Devlieghere, F. and Debevere, L.V.J. (2004), New preservation technologies: possibilities and limitations. Int. Dairy J., 14, 273-285.

Fiorentini, A.M.; Ernani, S.S.; Porto, A.C.S.; Jaciara, Z.M. and Franco, B.D.G.M. (2001), Influence of bacteriocins produced by Lactococcus plantarum $\mathrm{BN}$ in the shelf-lie of refrigerated bovine meat. Braz. $J$. Microbiol., 32, 42-46.

Freitas, W.C.; Souza, E.L. and Travassos, A.E.R. (2004), Ocorrência de Staphylococcus spp. em massa refrigerada tipo pizza pronta. Hig. Alim., 122, 67-70.

Kominsky, G.M.R. (1999), Avaliação da sensibilidade de microrganismos selecionados a diferentes concentrações de nisina em salsichas comuns e de frango. Hig. Alim., 13, 56-62.

Moreno, I.; Learyer, A.L.S. and Leitão, M.F.F. (2000), Characterization of bacteriocins produced by Lactobacillus lactis strains. Braz. J. Microbiol., 31, 183-191.
Nilsson, L.; Chen, Y.; Chikinds, M.L.; Huss, H.H.; Gran, L. and Monteville, T.J. (2000), Carbon dioxide and nisin act synergistically on Listeria monocytogenes. Appl. Environ. Microbiol., 66, 769774.

Rowan, N.J. (1999), Evidence that inimical foodpreservation barriers alter microbial resistance, cell morphology and virulence. Trend. Food Scien. Technol., 10, 251-270.

Shefet, S.M.; Sheldon, B.W. and Klamenhammer, T.R. (1995), Efficacy of optimized nisin-treatments to inhibit Salmonella typhimurium and extend shelf-life to inhibit broiler carcasses. J. Food Protect., 58, 1077-1082.

Stevens, K.A.; Sheldon, W.; Klapes, A. and Klamenhammer, R. (1992), Effect of treatment and conditions on nisin inactivation of Gram-negative bacteria. J. Food Protect., 55, 763-766.

Trabulsi, L.R.; Althertum, F.; Gompertz, O.F. and Candeias, J.A.N. (2002), Microbiologia. Atheneu: São Paulo.

Vanderzant, C. and Splittstoesser, D.E. (1992), Compendium of methods for the microbiological examination of foods. American Public Health Association: Washington. 
PÁGINA

EM

BRANCO 